\title{
Corrosion Inhibition of Mild Steel in Sulfuric Acid Solution by Houttuynia Cordata Extract
}

\author{
Xingwen Zheng ${ }^{1,2, *}$, Min Gong ${ }^{2}$, Qiang $\mathrm{Li}^{1}$ \\ ${ }^{1}$ School of Chemical and Environmental Engineering, Sichuan University of Science \& Engineering, \\ Zigong 643000, China \\ ${ }^{2}$ Key Laboratory of Material Corrosion and Protection of Sichuan Province, Zigong 643000, China \\ *E-mail: zxwasd@126.com
}

doi: $10.20964 / 2017.07 .03$

Received: 28 February 2017 / Accepted: 21 April 2017 / Published: 12 June 2017

\begin{abstract}
The inhibition performance and mechanism of Houttuynia cordata extract (HCE) for the corrosion of mild steel in $0.5 \mathrm{M} \mathrm{H}_{2} \mathrm{SO}_{4}$ were investigated using weight loss method, electrochemical measurements and scanning electron microscope (SEM). The results revealed that HCE was an effective mixed-type inhibitor with a predominantly cathodic action for mild steel in $0.5 \mathrm{M} \mathrm{H}_{2} \mathrm{SO}_{4}$ solution, its inhibition efficiency increases with the increase of the concentration of HCE, and when the concentration of HCE reaches $0.75 \mathrm{~g} / \mathrm{L}$, the inhibition efficiency is up to $90 \%$ at $298 \mathrm{~K}$. The adsorption of HCE on steel surface obeyed Langmuir adsorption isotherm, thus the thermodynamic and kinetic parameters were calculated and discussed.
\end{abstract}

Keywords: Houttuynia cordata; Mild steel; $\mathrm{H}_{2} \mathrm{SO}_{4}$; Corrosion inhibitor; Adsorption.

\section{FULL TEXT}

(C) 2017 The Authors. Published by ESG (www.electrochemsci.org). This article is an open access article distributed under the terms and conditions of the Creative Commons Attribution license (http://creativecommons.org/licenses/by/4.0/). 